J. Dairy Sci. 92:247-255

doi:10.3168/jds.2008-1386

(c) American Dairy Science Association, 2009.

\title{
Effects of strain of Holstein-Friesian and concentrate supplementation on the fatty acid composition of milk fat of dairy cows grazing pasture in early lactation
}

\author{
W. J. Wales, ${ }^{\star 1}$ E. S. Kolver,$\dagger^{2}$ A. R. Egan, $\ddagger^{3}$ and J. R. Roche $\dagger$ \\ *Future Farming Systems Research, Department of Primary Industries, Kyabram Centre, 120 Cooma Road, Kyabram, Victoria 3620, Australia \\ †DairyNZ (formerly Dexcel Ltd.), Morrinsville Rd, Hamilton, New Zealand \\ łLand and Food Resources, The University of Melbourne, Parkville, Victoria, 3010, Australia
}

\begin{abstract}
The effect of a grain-based concentrate supplement on fatty acid (FA) intake and concentration of milk FA in early lactation was investigated in grazing dairy cows that differed in their country of origin and in their estimated breeding value for milk yield. It was hypothesized that Holstein-Friesian cows of North American (NA) origin would produce milk lower in milk fat than those of New Zealand (NZ) origin, and that the difference would be associated with lower de novo synthesis of FA. In comparison, increasing the intake of concentrates should have the same effect on the FA composition of the milk from both strains. Fifty-four cows were randomly assigned in a factorial arrangement to treatments including 3 amounts of concentrate daily $[0,3$, and $6 \mathrm{~kg}$ of dry matter $(\mathrm{DM}) / \mathrm{cow}]$ and the 2 strains. The barley/steam-flaked corn concentrate contained 3.5\% DM FA, with C18:2, C16:0, and C18:1 contributing 48, 18, and $16 \%$ of the total FA. The pasture consumed by the cows contained $4.6 \% \mathrm{DM}$ FA with C18:3, C16:0, and C18:1 contributing 51, 10, and $10 \%$ of the FA, respectively. Pasture DM intake decreased linearly with supplementation, but total DM intake was not different between concentrate or strain treatments, averaging $16.2 \mathrm{~kg}$ of $\mathrm{DM} / \mathrm{cow}$, with cows consuming $720 \mathrm{~g}$ of total FA/d. Cows of the NA strain had lesser concentrations of milk fat compared with $\mathrm{NZ}$ cows (3.58 vs. $3.95 \%)$. Milk fat from the NA cows had lesser concentrations of C6:0, C8:0, C10:0, C12:0, $\mathrm{C} 14: 0$, and $\mathrm{C} 16: 0$, and greater concentrations of cis-9 C18:1, C18:2, and cis-9, trans-11 C18:2, than NZ cows. These changes indicated that in milk from NA cows had a lesser concentration of de novo synthesized FA
\end{abstract}

Received May 23, 2008.

Accepted September 4, 2008.

${ }^{1}$ Corresponding author: bill.wales@dpi.vic.gov.au

${ }^{2}$ Present address: Synlait Ltd., Te Pirita Road, RD13, Rakaia, New Zealand.

${ }^{3}$ Present address: 145 Stirling St., Bunbury, Western Australia, 6230, Australia. and a greater concentration of FA of dietary origin. Milk fat concentration was not affected by concentrate supplementation. Increasing concentrate intake resulted in linear increases in the concentrations of C10:0, C12:0, C14:0, and C18:2 FA in milk fat, and a linear decrease in the concentration of C4:0 FA. The combination of NA cows fed pasture alone resulted in a FA composition of milk that was potentially most beneficial from a human health perspective; however, this would need to be balanced against other aspects of the productivity of these animals.

Key words: strain, concentrate supplementation, grazing dairy cow, milk fat composition

\section{INTRODUCTION}

Manipulating the proportion of particular fatty acids (FA) in milk fat has the potential to provide positive benefits for human health ranging from hypocholesterolic effects to inhibition of some cancers. Elevated levels of cholesterol in humans are likely to be associated with C14:0 and C16:0 FA consumption (Grundy and Denke, 1990) and cancer inhibition has been linked to C4:0 and the cis-9, trans-11 C18:2 isomer of conjugated linoleic acid (CLA; e.g., Ip et al., 1999; Parodi, 2003). The C4:0 to C14:0 FA and approximately one-half of C16:0 are synthesized de novo in the mammary gland from the short-chain FA arising from microbial digestion of carbohydrates in the rumen, whereas the remaining C16:0 and virtually all the C18 FA are derived from circulating blood lipids, with blood lipids coming directly from the diet or from FA mobilized from triacylglycerol stores within adipose tissue (Bauman and Davis, 1974; Grummer, 1991). De novo synthesis is influenced by dietary factors that affect the supply of acetate and butyrate from the rumen (Murphy, 2000), and animal factors such as breed can also have significant impacts on milk fat (Palmquist et al., 1993). Generally, dairy breeds with high milk fat concentrations also have high concentrations of de novo synthesized FA and saturated FA (Palmquist et al., 1993). Within a breed, Kolver et 
al. (2002) and Roche et al. (2006) showed that selection for milk yield altered milk fat concentration, with cows of a North American (NA) strain of Holstein-Friesian having lower milk fat concentrations than those of New Zealand (NZ) origin offered a similar diet. It is not clear, however, whether the association between milk fat concentration and de novo synthesis of FA found between breeds holds for strains within a breed. In addition, milk fat concentration can be reduced by dietary NDF insufficiency, which is often associated with including concentrates in pasture-based diets; in this case, the FA from de novo synthesis may increase as milk fat concentrations decline (Stockdale et al., 2003; Wijesundera et al., 2003). Therefore, with this as background, the effects of strain of Holstein-Friesian and feeding concentrate-based supplements on milk FA composition were investigated in dairy cows grazing pasture in early lactation. It was hypothesized that Holstein-Friesian cows of NA origin would have lower milk fat concentrations than NZ Friesians, that this difference would be associated with lower de novo synthesis of FA, and that increasing the intake of concentrates would have the same effect on the FA composition of the milk from both strains.

\section{MATERIALS AND METHODS}

\section{Animals and Experimental Design}

A 10-d intensive measurement period, beginning about 2 mo after calving (July 28, $2002 \pm 19.9$ d), was conducted in October (spring) 2002 within a multilactation experiment, described previously by Roche et al. (2006), at Hamilton, New Zealand. All procedures were approved by the Ruakura Animal Ethics Committee, Hamilton, New Zealand. The main experiment was designed to investigate strain $\times$ diet interactions with Holstein-Friesian genetics of NA and NZ origin. Full information about the background of the 2 strains has been provided by Roche et al. (2006). Fifty-four Holstein-Friesian cows (16 primiparous, 38 multiparous) grazed as a single herd throughout and were individually fed concentrate supplements at each milking. At the start of the intensive measurement period (58 \pm 21.5 and $66 \pm 17.7$ DIM for the NA and NZ cows, respectively), the NA cows were heavier $(526 \pm 83.5$ vs. $466 \pm 74.8 \mathrm{~kg})$ but had a lower BCS (3.6 \pm 0.55 vs. $3.9 \pm 0.57$ units on a 10-point scale; Roche et al., 2004) than the NZ cows. The cows from each strain received 1 of 3 amounts of concentrates daily ( 0,3 , or $6 \mathrm{~kg}$ of DM/ cow) in a $2 \times 3$ factorial arrangement. Cows grazed perennial ryegrass (Lolium perenne)-based pasture at a daily allowance, measured to ground level, of $59 \mathrm{~kg}$ of $\mathrm{DM} /$ cow.
Cows had been allocated to treatments by stratified randomization based on BW, BCS, milk yield, milk fat and protein concentrations, and cow estimated breeding values for production characteristics. There were 9 cows per treatment. Individual feeding of supplements commenced immediately after calving. Concentrates were fed to all cows at a daily rate of $2 \mathrm{~kg}$ of $\mathrm{DM} / \mathrm{cow}$ for at least $10 \mathrm{~d}$ before calving.

\section{Feedstuffs and Measurements}

The concentrate consisted of $65 \%$ rolled barley grain, $35 \%$ steam-flaked corn (Zea mays) grain, and $5 \%$ molasses. The supplement was offered to cows in 2 equal amounts after the morning and afternoon milkings. Concentrate refusals were collected and samples dried at $100^{\circ} \mathrm{C}$ for $24 \mathrm{~h}$ for determination of concentrate DM intake.

A rising plate meter (Farmworks, Palmerston North, New Zealand) was used to estimate pasture mass before grazing to calculate pasture allowance. Two hundred readings of pasture height were taken in the area to be grazed on the next day, and 27 quadrats $\left(0.125 \mathrm{~m}^{2}\right)$ were cut to ground level and dried at $100^{\circ} \mathrm{C}$ for $24 \mathrm{~h}$. These data were used to develop a regression equation relating pasture height to pasture mass:

$$
\begin{aligned}
& \text { Pasture mass }(\mathrm{kg} \text { of } \mathrm{DM} / \mathrm{ha})=118.6 \times \text { pasture } \\
& \text { height }(0.5 \mathrm{~cm})+507 ; \mathrm{r}^{2}=0.84 .4 ; \mathrm{n}=27 .
\end{aligned}
$$

The pasture allowance was offered in approximately equal amounts after each milking, with opportunity for cows to graze back over the morning area in the afternoon. The amount of pasture eaten by individual cows was assessed during the last $5 \mathrm{~d}$ of the measurement period using the alkane marker technique outlined by Kennedy et al. (2003). Each cow was orally dosed with a gelatin capsule containing $356 \mathrm{mg}$ of $\mathrm{C}_{32}$ alkane twice per day for $10 \mathrm{~d}$. Fecal samples were collected twice per day, immediately before milking, during the last 5 d. The fecal samples from the 5-d period were bulked within cow and stored at $-17^{\circ} \mathrm{C}$ to await alkane analysis. Samples of pasture, representative of that selected by cows based on observations of the previous day's postgrazing height, were plucked by hand and samples of concentrate offered to the cows receiving supplements were collected on each day of the measurement period, frozen, and freeze-dried for analysis of nutritive characteristics and alkane concentration. These samples were ground through a $1-\mathrm{mm}$ screen and 5.0 g DM subsamples bulked over the measurement period for chemical analyses. The n-alkane contents (C25 to C36) of the pasture and feces were analyzed by GC. 
The ratio of herbage C33 (tritriacontane) to dosed C32 (n-dotriacontane) was used to estimate pasture intake. Estimates of daily herbage intake were calculated as follows:

$$
\begin{aligned}
& \text { Daily pasture DMI }(\mathrm{kg} / \mathrm{cow})= \\
& \frac{\mathrm{F}_{\mathrm{i}} / \mathrm{F}_{\mathrm{j}} \cdot\left(\mathrm{D}_{\mathrm{j}}+\mathrm{I}_{\mathrm{S}} \cdot \mathrm{S}_{\mathrm{j}}\right)-\mathrm{I}_{\mathrm{S}} \cdot \mathrm{S}_{\mathrm{i}}}{\mathrm{P}_{\mathrm{i}}-\left(\mathrm{P}_{\mathrm{j}} \cdot \mathrm{F}_{\mathrm{i}} / \mathrm{F}_{\mathrm{j}}\right)}
\end{aligned}
$$

where $\mathrm{F}_{\mathrm{i}}, \mathrm{S}_{\mathrm{i}}$, and $\mathrm{P}_{\mathrm{i}}$ are the concentrations $(\mathrm{mg} / \mathrm{kg}$ of $\mathrm{DM}$ ) of the natural odd-chain n-alkane (C33) in feces, supplement, and pasture, respectively; $F_{j}, S_{j}$, and $P_{j}$ are the concentrations $(\mathrm{mg} / \mathrm{kg}$ of $\mathrm{DM})$ of the dosed even-chain n-alkane (C32) in feces, supplements, and pasture, respectively, and $D_{j}$ and $I_{S}$ are the dose rate (mg/d) of the even-chain n-alkane (C32) and supplement intake, respectively.

Pasture samples representative of that consumed by cows and concentrate samples were analyzed for $\mathrm{N}$ by Kjeldahl digestion (Kjeltec 1035 analyzer, Tecator, Höganäs, Sweden) with CP concentration calculated as $\mathrm{N} \times 6.25$. Organic matter concentration was determined according to AOAC (1990), and digestibility of DM (DMD) by near infrared reflectance spectroscopy (Ulyatt et al., 1995). Metabolizable energy (MJ/kg of DM) was calculated from DMD using DMD $\times 0.17$ - 2.0 (SCA, 1990). Neutral detergent fiber was determined using the method described by Van Soest et al. (1991).

Pasture and concentrate lipids were extracted and methylated according to the 1-step method of Garces and Mancha (1993). To $0.2 \mathrm{~g}$ of freeze-dried pasture, 6.6 $\mathrm{mL}$ of methanol:toluene:2,2-dimethoxypropane:sulfuric acid (39:20:5:2 vol/vol) was added, followed by $3.4 \mathrm{~mL}$ of n-heptane. The mixture was heated to $80^{\circ} \mathrm{C}$ in dry heating blocks, shaken vigorously, and then allowed to stand at room temperature to form a single phase and returned to the heating block for a further $2 \mathrm{~h}$. The mixture was removed and allowed to cool to room temperature, then shaken vigorously to allow phases to separate. The upper phase was subsampled $(1 \mathrm{~mL})$ for GC analysis. Analyses of FA composition were performed on a Hewlett Packard 5890 Series II GC equipped with a RTX-2330 column $(30 \mathrm{~m} \times 0.32 \mathrm{~mm}$ i.d. and $0.2-$ $\mu \mathrm{m}$ film thickness; Restek Corp., Bellefonte, PA) using helium gas as a carrier at a flow rate of $1.4 \mathrm{~mL} / \mathrm{min}$.

Cows were milked twice daily commencing at 0400 and $1400 \mathrm{~h}$. Individual milk yields were recorded and aliquot samples taken during the 5-d DMI measurement period. The milk samples were analyzed for fat, protein, and lactose concentrations using an infrared milk analyzer (FT120, Foss Electric, Hillerød, Denmark). Milk fat was extracted from fresh samples using a method based on the Röse-Gottlieb gravimetric method (International Dairy Federation, 1987) and stored at $-20^{\circ} \mathrm{C}$ until analyzed for FA composition. Concentrations of FA methyl esters in milk fat were determined by GC, following methylation with sodium methoxide (Slover and Lanza, 1979). Analyses were conducted using an Agilent 6890 GC with auto-sampler, auto-injector, and flame ionization detector (Agilent Technologies, Santa Clara, CA), and with a RTX-2330 column (105 m × $0.25 \mathrm{~mm}$ i.d. and $0.2-\mu \mathrm{m}$ film thickness), using helium as the carrier gas at a rate of $1.4 \mathrm{~mL} / \mathrm{min}$. Peak identification was by retention time comparisons with Sigma Chemical Corporation (St. Louis, MO) standards 18919 (37 FAME 4:0 - 24:0) included every 15 samples.

The BCS of each cow was assessed each week using a 10-point scale (Roche et al., 2004), and BW was measured following an a.m. milking at the start of the investigation.

The $\Delta^{9}$-desaturase index was used as an indicator of $\Delta^{9}$-desaturase activity and was calculated using 4 pairs of fatty acids that are substrates and products for $\Delta^{9}$-desaturase. The $\Delta^{9}$-desaturase index was defined as [sum of $\Delta^{9}$-desaturase products] / [sum of $\Delta^{9}$ desaturase substrates + products] and was calculated as [C14:1+C16:1+cis-9 C18:1+cis-9,trans-11 C18:2]/[C14 $: 0+\mathrm{C} 14: 1+\mathrm{C} 16: 0+\mathrm{C} 16: 1+\mathrm{C} 18: 0+$ cis-9 $\mathrm{C} 18: 1+$ trans -11 C18:1+cis-9, trans-11 C18:2].

\section{Statistical Analyses}

Treatment responses were compared by ANOVA employing a factorial design with level of daily concentrate supplement $(0,3$, or $6 \mathrm{~kg}$ of $\mathrm{DM} / \mathrm{cow})$ and strain of Holstein-Friesian (NZ or NA) as factors (Genstat 6, 2002; Lawes Agricultural Trust, Rothamsted, UK, 2002), with significant differences between factors established at $P<0.05$. Orthogonal contrasts were conducted using concentrate as the independent variable to determine the significance of linear or quadratic relationships. No significant quadratic relationships were detected. A significant concentrate effect indicates a significant linear relationship. Interactions between strain and concentrate were tested, but except for concentration of $\mathrm{C} 18: 3$ in milk fat, interactions were not significant. Body condition score recorded weekly from 2 wk pre-measurements to 2 wk post-measurements were used to estimate BCS change for each cow using linear regression. In addition, relationships associated with some key FA were investigated by regression analysis. In all of the statistical analyses, a cow was the experimental unit. Two NA cows, 1 from each of the 0 and $3 \mathrm{~kg}$ DM concentrate/cow treatments were excluded from the analyses because they were being 
Table 1. Nutrient characteristics (\% DM) of the pasture (sampled to reflect that consumed by cows) and concentrate

\begin{tabular}{lcc}
\hline Characteristic & Perennial ryegrass & Concentrate $^{1}$ \\
\hline DM digestibility & 83.5 & 86.2 \\
NDF & 44.6 & 14.3 \\
CP & 24.4 & 10.4 \\
ME, MJ/kg of DM & 12.2 & 12.7 \\
Fatty acids & & \\
C14:0 & 0.01 & 0 \\
C16:0 & 0.44 & 0.61 \\
C16:1 & 0.07 & 0 \\
C18:0 & 0.05 & 0.05 \\
C18:1 & 0.46 & 0.55 \\
C18:2 & 0.34 & 1.68 \\
Other & 2.37 & 0.10 \\
Total & 0.89 & 0.48 \\
\hline
\end{tabular}

${ }^{1}$ Barley $65 \%$ DM, steam-flaked corn 30\% DM, molasses 5\% DM.

treated for lameness and grazed in a separate paddock during part of the study.

\section{RESULTS}

The pasture offered to cows had a rising plate meter height of $10.7( \pm 0.65 \mathrm{SD}) \mathrm{cm}$ and a pasture mass (to ground level) of $3.0( \pm 0.15) \mathrm{t}$ of DM/ha, and comprised $93 \%$ perennial ryegrass, $1 \%$ white clover, and $6 \%$ dead material. The herbage consumed by the cows was highly digestible and contained $4.6 \%$ DM FA, with C18:3 the most abundant (51\% of the FA; Table 1 ). The concentrate was more digestible than the pasture and contained 3.5\% DM FA, with C18:2 the most abundant ( $48 \%$ of the FA; Table 1). Dietary NDF and $\mathrm{CP}$ concentrations for the cows consuming 0,3 , and 6 $\mathrm{kg} \mathrm{DM}$ of concentrate were 44.6, 39.6, and $35.6 \% \mathrm{DM}$ and 24.4, 22.1, and 20.3\%, respectively.

Pasture DMI decreased linearly with concentrate supplementation, but there was no effect of strain on pasture DM, total DM, or ME intakes (Table 2). Because of the high allowance of pasture offered to the cows of $59 \mathrm{~kg}$ of DM/day, substitution rates of pasture for supplement were relatively high at 0.6 and $0.8 \mathrm{~kg}$ of $\mathrm{DM}$ reduction in pasture intake $/ \mathrm{kg}$ of $\mathrm{DM}$ concentrate consumed at the 3 and $6 \mathrm{~kg}$ DM concentrate/cow treatments, respectively. Daily intakes of total FA were not affected by either supplementation or strain; however, intakes of individual FA did vary with supplementation but not strain (Table 2). Intake of C14:0, C16:1, and C18:3 FA declined, and that of C16:0 and C18:2 FA increased with increasing concentrate supplementation.

Yields of milk, fat, protein, and lactose were not affected by either strain or concentrate treatments (Table 3 ). Concentrations of milk fat, protein, and lactose were not affected by concentrate supplementation, but cows of NA origin produced milk with less milk fat compared with NZ cows. There were no significant differences in BCS change over the $28 \mathrm{~d}$ to the end of the intensive measurement period.

Both strain and concentrate treatments affected the concentrations of FA in milk fat (Table 4). Compared with NZ cows, those of NA origin had lesser concentrations of C6:0, C8:0, C10:0, C12:0, C14:0, cis-C14:1, C15:0, and C16:0, and greater concentrations of C17:0, cis-9 C18:1, C18:2, and cis-9, trans-11 CLA. This resulted in a lesser concentration of de novo synthesized FA and a greater concentration of FA of dietary origin. The $\Delta^{9}$-desaturase index was lower $(P<0.01)$ for NZ compared with the NA strain (0.30 vs. 0.35 , $\mathrm{SED}=0.018)$ indicating differences between strains in the activity of the $\Delta^{9}$-desaturase enzyme. Concentrate supplementation resulted in linear increases in the concentrations of C10:0, C12:0, C14:0, C15:0, cis-11 C18:1, and $\mathrm{C} 18: 2$, and a decrease in the concentration of $\mathrm{C} 4: 0$ FA. Concentrations of de novo synthesized FA increased linearly with concentrate supplementation, whereas

Table 2. Daily intakes of DM, ME, and fatty acids of cows of either New Zealand (NZ) or North American (NA) Holstein-Friesian strains grazing perennial ryegrass-dominant pasture and offered 0,3 , or $6 \mathrm{~kg}$ DM concentrate

\begin{tabular}{|c|c|c|c|c|c|c|c|c|c|c|}
\hline Item & \multicolumn{4}{|c|}{ Concentrate $(\mathrm{C})$} & \multicolumn{3}{|c|}{ Strain $(\mathrm{S})$} & \multicolumn{3}{|c|}{$P$-value } \\
\hline Pasture DMI, kg/cow & 15.4 & 13.8 & 11.7 & 0.92 & 13.6 & 13.7 & 0.75 & $<0.01$ & 0.86 & 0.60 \\
\hline Total DMI, kg/cow & 15.4 & 16.4 & 16.6 & 0.94 & 16.1 & 16.2 & 0.77 & 0.39 & 0.93 & 0.61 \\
\hline ME intake, MJ/cow & 188 & 202 & 205 & 11.5 & 198 & 199 & 9.4 & 0.30 & 0.93 & 0.61 \\
\hline \multicolumn{11}{|l|}{ Fatty acid intake, g/cow } \\
\hline C16:1 & 10.8 & 9.7 & 8.2 & 0.64 & 9.5 & 9.6 & 0.53 & $<0.01$ & 0.86 & 0.60 \\
\hline C18:0 & 7.7 & 8.2 & 8.3 & 0.47 & 8.1 & 8.1 & 0.39 & 0.39 & 0.93 & 0.61 \\
\hline C18:1 & 70.9 & 78.0 & 80.9 & 4.38 & 76.5 & 76.7 & 3.57 & $<0.05$ & 0.94 & 0.61 \\
\hline $\mathrm{C} 18: 2$ & 52.4 & 91.1 & 122.1 & 4.06 & 88.8 & 88.2 & 3.32 & $<0.01$ & 0.85 & 0.55 \\
\hline $\mathrm{C} 18: 3$ & 365 & 330 & 283 & 21.8 & 325 & 328 & 17.8 & $<0.01$ & 0.87 & 0.60 \\
\hline Total & 715 & 732 & 714 & 43.4 & 718 & 722 & 35.5 & 0.901 & 0.91 & 0.61 \\
\hline
\end{tabular}


Table 3. Daily milk production and composition, and BCS change, of cows of either New Zealand (NZ) or North American (NA) Holstein Friesian strains grazing perennial ryegrass-dominant pasture and offered 0,3 , or $6 \mathrm{~kg}$ DM concentrate

\begin{tabular}{|c|c|c|c|c|c|c|c|c|c|c|}
\hline \multirow[b]{2}{*}{ Item } & \multicolumn{4}{|c|}{ Concentrate $(\mathrm{C})$} & \multicolumn{3}{|c|}{ Strain $(\mathrm{S})$} & \multicolumn{3}{|c|}{$P$-value } \\
\hline & 0 & 3 & 6 & SED & $\mathrm{NZ}$ & NA & SED & $\mathrm{C}$ & S & $\mathrm{C} \times \mathrm{S}$ \\
\hline Milk fat concentration, $\%$ & 3.89 & 3.72 & 3.69 & 0.139 & 3.95 & 3.58 & 0.113 & 0.28 & $<0.01$ & 0.61 \\
\hline Milk protein concentration, $\%$ & 3.37 & 3.45 & 3.57 & 0.079 & 3.52 & 3.40 & 0.064 & 0.05 & 0.06 & 0.95 \\
\hline Milk lactose concentration, $\%$ & 4.92 & 5.02 & 5.03 & 0.048 & 4.97 & 5.01 & 0.040 & 0.07 & 0.26 & 0.33 \\
\hline Milk fat yield, $\mathrm{kg} / \mathrm{cow}$ & 1.01 & 1.04 & 1.03 & 0.082 & 1.03 & 1.03 & 0.067 & 0.90 & 0.98 & 0.94 \\
\hline BCS change (unit) ${ }^{1}$ & -0.46 & -0.19 & -0.33 & 0.017 & -0.27 & -0.38 & 0.138 & 0.29 & 0.42 & 0.25 \\
\hline
\end{tabular}

${ }^{1}$ Estimated by regression analysis of weekly data for $28 \mathrm{~d}$ to the end of the experimental period.

those of dietary origin decreased linearly with concentrate supplementation. There was an interaction $(P<$ $0.05)$ between strain and concentrate supplementation for C18:3. Offering 0,3 , and $6 \mathrm{~kg}$ of DM concentrate to NA cows resulted in C18:3 concentrations of 1.1, 1.0 , and $0.8 \%$ of total FA, respectively, compared with concentrations of $0.8,0.8$, and $0.7 \%$ in NZ cows (SED $=0.06)$.

Strain and concentrate supplementation also affected the yields of some individual FA (Table 5) although differences were not as pronounced as those for milk FA concentrations. Cows of the NA strain had lesser yields of C8:0, C10:0, C12:0, C14:0, and C15:0 and greater $(P<0.05)$ yields of $\mathrm{C} 17: 0$, cis-9 $\mathrm{C} 18: 1$, cis-9, trans-11 CLA, and C18:3 than those originating from NZ. Concentrate supplementation resulted in linear increases in the yields of $\mathrm{C} 12: 0, \mathrm{C} 15: 0$, and $\mathrm{C} 18: 2$. No differences were recorded, however, in the total yields of $\mathrm{FA}$ for the presumptive categories of de novo synthesized FA or FA of dietary origin.

\section{DISCUSSION}

Cows of NA origin had lesser concentrations of milk fat and reduced proportions and yield of de novo synthesized FA in milk fat compared with the NZ cows, thereby supporting our hypothesis. The reduced milk fat concentration is in agreement with several studies comparing NZ and NA strains; for example, Kolver et al. (2002) reported a difference in milk fat concentration of 0.77 percentage units for unsupplemented cows of either NA or NZ origin grazing pasture over a full lactation. Genetic selection for increased milk fat concentration has generally led to an increase in the proportion of short-chain FA and a decrease in the proportion of long-chain FA in milk fat (Palmquist et al., 1993). The lesser milk fat concentration of the NA cows in this study was associated with significantly reduced de novo synthesis despite the similar intake of FA be- tween strains and the likelihood that similar amounts of mobilized adipose tissue were contributing to milk FA in all treatments at the time of the measurement period (see Table 3 and Roche et al., 2006).

Concentrate supplementation did not significantly affect the concentration of milk fat or the yield of de novo synthesized FA, but it did linearly increase the proportion of de novo synthesized FA. Several studies have reported reduced milk fat concentrations in grazing cows supplemented with concentrate; however, the depression has not been large on average. Bargo et al. (2003) reported increased milk yields by up to $22 \%$, but decreased milk fat concentrations of only $6 \%$, when up to $10 \mathrm{~kg}$ of concentrates were fed. However, over 2 lactations using the same cows and treatments (Roche et al., 2006), average milk fat concentrations were $9 \%$ lower when the 6-kg DM treatment was compared with the 0 treatment. Differences in milk fat are likely to have been greater in other stages of lactation. The lack of effect of concentrate intake on milk fat concentration was not surprising because the lowest NDF in the diets fed in the current study (36\%) would indicate that the requirements for NDF were met (NRC, 2001). In addition, with $30 \%$ of the concentrate being steam-flaked corn, which has reduced ruminal degradability characteristics compared with rolled barley (Granzin, 2004), depressions in ruminal fluid $\mathrm{pH}$ due to the feeding of concentrates were likely to have been small. Consistent with this, Kolver and de Veth (2002) established a positive linear relationship between ruminal fluid $\mathrm{pH}$ and milk fat concentration in an analysis of 23 grazing experiments with lactating cows.

Recent research into factors influencing milk fat production has focused on inhibitory compounds that primarily reduce de novo synthesis in cows receiving TMR, with the key compound investigated being trans-10, cis12 C18:2 (e.g., Baumgard et al., 2002; Perfield et al., 2006). Acetate and butyrate contribute equally to the first 4 carbons in de novo synthesized FA (Palmquist 
Table 4. Concentrations of fatty acids ${ }^{1}$ (\% of total fatty acids) in the milk fat of cows of either New Zealand (NZ) or North American (NA) Holstein-Friesian strains grazing perennial ryegrass-dominant pasture and offered 0,3 , or $6 \mathrm{~kg}$ DM concentrate

\begin{tabular}{|c|c|c|c|c|c|c|c|c|c|c|}
\hline \multirow[b]{2}{*}{ Fatty acid } & \multicolumn{4}{|c|}{ Concentrate $(\mathrm{C})$} & \multicolumn{3}{|c|}{ Strain $(\mathrm{S})$} & \multicolumn{3}{|c|}{$P$-value } \\
\hline & 0 & 3 & 6 & SED & $\mathrm{NZ}$ & NA & SED & $\mathrm{C}$ & $\mathrm{S}$ & $\mathrm{C} \times \mathrm{S}$ \\
\hline C6:0 & 2.2 & 2.2 & 2.3 & 0.06 & 2.3 & 2.1 & 0.05 & 0.56 & $<0.01$ & 0.49 \\
\hline $\mathrm{C} 8: 0$ & 1.3 & 1.3 & 1.4 & 0.06 & 1.4 & 1.2 & 0.05 & 0.07 & $<0.01$ & 0.68 \\
\hline C10:0 & 2.6 & 2.9 & 3.3 & 0.20 & 3.3 & 3.0 & 0.16 & $<0.01$ & $<0.01$ & 0.85 \\
\hline $\mathrm{C} 12: 0$ & 2.8 & 3.1 & 3.7 & 0.26 & 3.6 & 2.7 & 0.21 & $<0.01$ & $<0.01$ & 0.90 \\
\hline Cis-C14:1 & 0.7 & 0.7 & 0.8 & 0.05 & 0.8 & 0.7 & 0.04 & 0.10 & $<0.05$ & 0.61 \\
\hline C15:0 & 1.1 & 1.4 & 1.5 & 0.09 & 1.4 & 1.2 & 0.07 & $<0.01$ & $<0.05$ & 0.39 \\
\hline C16:0 & 23.2 & 24.2 & 24.6 & 0.77 & 25.0 & 23.0 & 0.63 & 0.20 & $<0.01$ & 0.95 \\
\hline C16:1 & 1.1 & 1.0 & 1.1 & 0.09 & 1.1 & 1.1 & 0.08 & 0.65 & 0.87 & 0.84 \\
\hline $\mathrm{C} 17: 0$ & 0.6 & 0.6 & 0.7 & 0.02 & 0.6 & 0.7 & 0.01 & $<0.05$ & $<0.01$ & 0.26 \\
\hline C18:0 & 11.9 & 11.5 & 10.8 & 0.50 & 11.1 & 11.7 & 0.41 & 0.07 & 0.12 & 0.62 \\
\hline Trans-9 C18:1 & 0.3 & 0.3 & 0.4 & 0.07 & 0.3 & 0.3 & 0.06 & 0.39 & 0.40 & 0.31 \\
\hline Other trans CLA & 0.1 & 0.1 & 0 & 0.03 & 0.1 & 0.1 & 0.02 & 0.20 & 0.51 & 0.31 \\
\hline C20:0 & 0.1 & 0.1 & 0.1 & 0.02 & 0.1 & 0.1 & 0.02 & 0.72 & 0.44 & 0.37 \\
\hline De novo ${ }^{3}$ & 36.7 & 39.0 & 40.5 & 1.25 & 41.1 & 36.4 & 1.02 & $<0.05$ & $<0.01$ & 0.93 \\
\hline Dietary $^{4}$ & 58.6 & 56.1 & 54.6 & 1.38 & 54.0 & 58.8 & 1.13 & 0.02 & $<0.01$ & 0.89 \\
\hline
\end{tabular}

${ }^{1}$ See text for results for $\mathrm{C} 18: 3$, because a significant interaction was identified.

${ }^{2}$ Conjugated linoleic acid.

${ }^{3}$ Estimated de novo synthesis, calculated as C4:0 to C15:0 and half C16 fatty acids.

${ }^{4}$ Dietary fatty acids, calculated as half C16 fatty acids and longer acids.

et al., 1969), whereas carbons for FA longer than C4:0 are sourced from acetate via malonyl CoA. De novo synthesis is regulated by specific FA, as incorporation of malonyl CoA into FA is strongly stimulated by some FA (e.g., C16:0) and inhibited by others (e.g., C18:0, cis-9 C18:1, C18:2, trans-10, cis-12 C18:2; Baumgard et al., 2002). It is suggested that, in this study, increasing the amount of concentrate feeding had no effect on milk fat production because there was no effect on de novo synthesis of FA.

It is generally assumed that about half the C16 FA are synthesized de novo in the mammary gland, with the rest being derived from circulating blood lipids (Grummer, 1991). The amount of C16:0 in milk fat in the current study was about 3 times greater than that consumed (Figure 1), the increased amount being necessarily due to de novo synthesis. Assuming that $60 \%$ of dietary fat is incorporated into milk fat (Moate et al., 2004), approximately $80 \%$ of the C16:0 in milk fat was synthesized de novo. Banks et al. (1976b) demonstrated a similar relationship with fat-rich diets (\% DM fat), but the slope of their relationship was close to unity. Low-fat (\% DM fat) diets increased C16:0 yield in milk fat to a greater degree than that predicted from the relationship with high-fat diets (Banks et al., 1976a, b), however, indicating that oil in the high-fat diets may have inhibited de novo synthesis of C16:0. The relatively low fat diets used in our experiment resulted in no significant changes in concentration or yield of C16:0, which probably demonstrates the important contribution of de novo synthesis to the amount of C16:0 present in milk fat.

There are some important potential implications of the responses in FA composition reported here because of the effects of specific FA on human health. For example $\mathrm{C} 16: 0$, and possibly $\mathrm{C} 12: 0$ and $\mathrm{C} 14: 0$, are nutritionally undesirable because they have been reported to increase the cholesterol concentration of low-density lipoproteins in humans (Grundy and Denke, 1990), a factor identified as a risk factor in the development of coronary heart disease. Cows consuming the pasture diet either had, or tended to have, the lowest concentrations and yields of C12:0, C14:0, and C16:0 in milk fat compared with cows supplemented with concentrates, and cows of NA origin were lower in all $3 \mathrm{FA}$ than the NZ cows, indicative of milk with improved healthpromoting characteristics.

Other components of milk fat, such as cis-9, trans-11 CLA, are considered beneficial for human health (e.g., Ip et al., 1999; Parodi, 2003). The CLA group of FA 


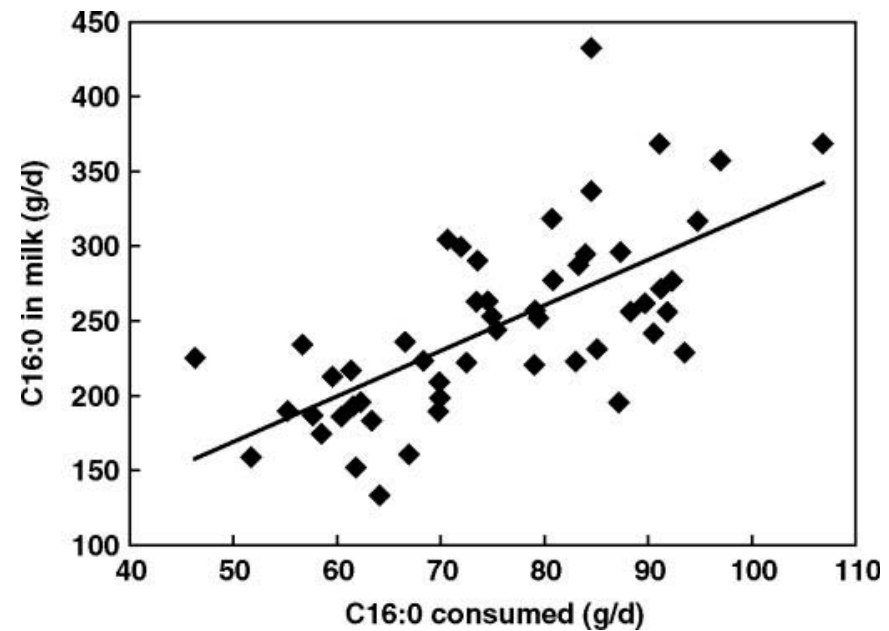

Figure 1. Association between the amount of $\mathrm{C} 16: 0$ consumed in the diet and that present in milk fat $\left(\mathrm{y}=3.04 \mathrm{x}+16.9 ; \mathrm{R}^{2}=45.1\right)$.

is an attribute of ruminant products, being formed as intermediary metabolites in the biohydrogenation of C18:2 to C18:0 during rumen fermentation. The positive relationship between cis-9, trans-11 CLA and trans-11 C18:1 (Figure 2) is consistent with the role of trans-11

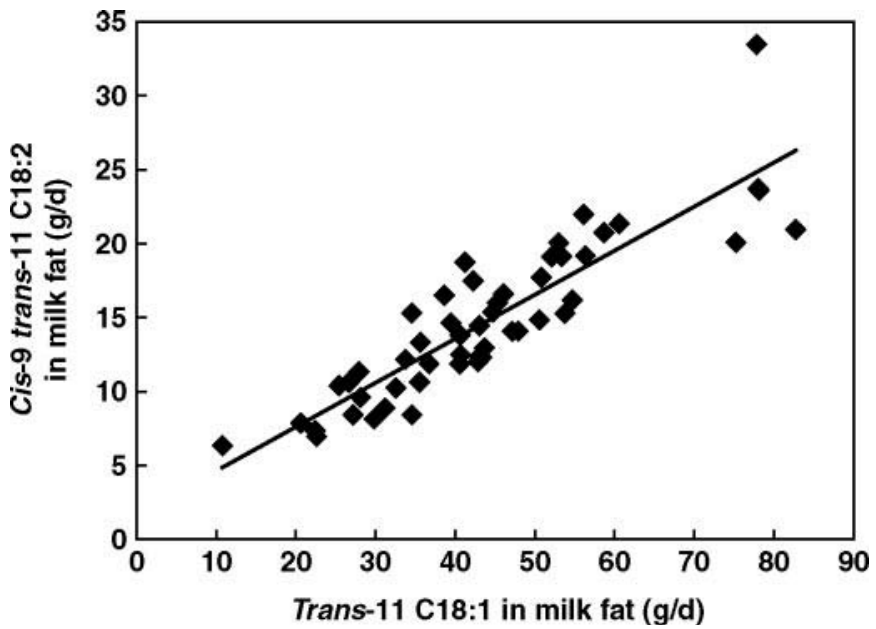

Figure 2. Association between amounts of trans-11 C18:1 and cis9, trans-11 C18:2 (conjugated linoleic acid) in milk fat $(\mathrm{y}=0.30 \mathrm{x}+$ $\left.1.7 ; \mathrm{R}^{2}=78.8\right)$.

C18:1 as a major source of CLA via the desaturase system in the mammary gland (Lock and Garnsworthy, 2003; Kay et al., 2004). In general, the milk fat of cows grazing pasture and receiving no supplements contains more CLA than that of cows given TMR-type diets

Table 5. Yields of milk fatty acids (g/d) from cows of either New Zealand (NZ) or North American (NA) Holstein-Friesian strains grazing perennial ryegrass-dominant pasture and offered 0,3 , or $6 \mathrm{~kg}$ of DM concentrate $(\mathrm{C})$

\begin{tabular}{|c|c|c|c|c|c|c|c|c|c|c|}
\hline Fatty acid & \multicolumn{4}{|c|}{ Grain (G) } & \multicolumn{3}{|c|}{ Strain (S) } & \multicolumn{3}{|c|}{$P$-value } \\
\hline $\mathrm{C} 4: 0$ & 40.9 & 42.0 & 38.8 & 3.76 & 40.5 & 40.6 & 3.07 & 0.69 & 0.99 & 0.86 \\
\hline $\mathrm{C} 8: 0$ & 12.5 & 13.5 & 14.2 & 1.12 & 14.6 & 12.2 & 0.92 & 0.32 & $<0.05$ & 0.79 \\
\hline C10:0 & 26.5 & 30.0 & 33.5 & 2.93 & 33.8 & 26.2 & 2.40 & 0.07 & $<0.01$ & 0.86 \\
\hline C12:0 & 27.8 & 31.7 & 37.0 & 3.31 & 36.9 & 27.4 & 2.71 & $<0.05$ & $<0.01$ & 0.87 \\
\hline Cis-C14:1 & 7.1 & 7.5 & 8.4 & 0.66 & 8.1 & 7.2 & 0.54 & 0.14 & 0.09 & 0.68 \\
\hline C15:0 & 10.7 & 13.7 & 14.7 & 0.85 & 13.7 & 12.3 & 0.70 & $<0.01$ & $<0.05$ & 0.44 \\
\hline C16:0 & 234 & 251 & 254 & 20.9 & 257 & 235 & 17.1 & 0.60 & 0.22 & 0.97 \\
\hline C16:1 & 11.8 & 11.3 & 11.7 & 1.74 & 11.7 & 11.5 & 1.42 & 0.97 & 0.93 & 0.79 \\
\hline C17:0 & 6.0 & 6.6 & 6.6 & 0.51 & 5.9 & 6.9 & 0.41 & 0.34 & $<0.05$ & 0.78 \\
\hline C18:0 & 119 & 120 & 113 & 10.3 & 114 & 120 & 8.4 & 0.74 & 0.47 & 0.95 \\
\hline Trans-9 C18:1 & 2.9 & 3.1 & 3.6 & 0.42 & 3.3 & 3.1 & 0.34 & 0.26 & 0.49 & 0.18 \\
\hline Other trans CLA & 0.5 & 0.8 & 0.2 & 0.28 & 0.4 & 0.6 & 0.23 & 0.13 & 0.36 & 0.33 \\
\hline C18:3 & 9.3 & 9.3 & 7.7 & 0.90 & 7.9 & 9.7 & 0.74 & 0.14 & $<0.05$ & 0.64 \\
\hline C20:0 & 0.5 & 0.7 & 0.7 & 0.19 & 0.7 & 0.6 & 0.16 & 0.48 & 0.32 & 0.24 \\
\hline De novo $^{2}$ & 369 & 403 & 417 & 32.2 & 422 & 371 & 26.3 & 0.32 & 0.06 & 0.98 \\
\hline Dietary $^{3}$ & 609 & 608 & 586 & 54.8 & 574 & 628 & 44.7 & 0.89 & 0.24 & 0.88 \\
\hline Total $^{4}$ & 1,007 & 1,042 & 1,034 & 81.5 & 1,027 & 1,029 & 66.5 & 0.90 & 0.98 & 0.94 \\
\hline
\end{tabular}

${ }^{1}$ Conjugated linoleic acid.

${ }^{2}$ Estimated de novo synthesis, calculated as C4:0 to C15:0 and half of the C16 fatty acids.

${ }^{3}$ Dietary fatty acids, calculated as half of the C16 fatty acids and longer acids.

${ }^{4}$ Includes other fatty acids not reported in table. 
(Dhiman et al., 1999; White et al., 2001; Kay et al., 2005). It has also been demonstrated that CLA declines with increasing amounts of grain feeding (Stockdale et al., 2003), although this is not always the case (Wijesundera et al., 2003). In the current study, in which no differences were detected in the CLA concentration or yield when more concentrate was consumed, it is likely that the different diets were all contributing similar amounts of long-chain FA that were biohydrogenated to a similar extent. In contrast, the greater CLA concentration in the NA cows compared with the NZ cows is consistent with the observed greater desaturase activity estimated using the $\Delta^{9}$-desaturase index (Kay et al., 2004). However, when Lawless et al. (1999) compared Irish and Dutch Holsteins fed pasture alone, where milk fat concentrations were 3.3 and $3.7 \%$, respectively, the average CLA concentrations were not different at 1.7 and $1.6 \%$ of total FA.

\section{CONCLUSIONS}

The milk from Holstein-Friesian cows of NA origin had a lesser concentration of de novo synthesized FA than milk from NZ Holstein-Friesians. This was interpreted as a genetic difference leading to differences in milk fat concentration that reflected reduced de novo synthesis, because intakes of individual FA and mobilization of body tissue were similar. In contrast, concentrate supplementation had less effect on the de novo synthesis of FA. The combination of NA cows fed pasture alone resulted in a FA composition of milk that would be perceived to be most beneficial from a human health perspective; however, this would need to be balanced against other aspects of the productivity of these animals.

\section{ACKNOWLEDGMENTS}

The authors acknowledge the technical assistance of Paula Thorne and the contributions of DairyNZ Lye dairy farm staff. This work was funded by New Zealand Dairy Farmers through DairyNZ (Hamilton, NZ) and the Victorian Department of Primary Industries.

\section{REFERENCES}

AOAC. 1990. Official Methods of Analysis. 15th ed. Association of Official Analytical Chemists, Arlington, VA.

Banks, W., J. L. Clapperton, and M. E. Ferrie. 1976b. Effect of feeding fat to dairy cows receiving a fat-deficient basal diet. 2. Fatty acid composition of the milk fat. J. Dairy Res. 43:219-227.

Banks, W., J. L. Clapperton, M. E. Ferrie, and A. G. Wilson. 1976a. Effect of feeding fat to dairy cows receiving a fat-deficient basal diet. 1. Milk yield and milk composition. J. Dairy Res. 43:213218.
Bargo, F., L. D. Muller, E. S. Kolver, and J. E. Delahoy. 2003. Invited review: Production and digestion of supplemented dairy cows on pasture. J. Dairy Sci. 86:1-42.

Bauman, D. E., and C. L. Davis. 1974. Biosynthesis of milk fat. Pages 31-75 in Lactation: A Comprehensive Treatise. Vol. 2. Biosynthesis and Secretion of Milk/Diseases. B. L. Larson and V. R. Smith, ed. Academic Press, New York, NY.

Baumgard, L. H., B. A. Matitashvili, B. A. Corl, and D. E. Bauman. 2002. Trans-10, cis-12 conjugated linoleic acid decreases lipogenic rates and expression of genes involved in milk lipid synthesis in dairy cows. J. Dairy Sci. 85:2155-2163.

Dhiman, T. R., G. R. Anand, L. D. Satter, and M. W. Pariza. 1999. Conjugated linoleic acid content of milk from cows fed different diets. J. Dairy Sci. 82:2146-2156.

Garces, R., and M. Mancha. 1993. One step lipid extraction and fatty acid methyl esters preparation from fresh plant tissue. Anal. Biochem. 211:139-143.

Granzin, B. C. 2004. Effects of supplement grain type and level of feeding on the milk production of early-lactation Holstein-Friesian cows grazing temperate and tropical pastures. Aust. J. Exp. Agric. 44:735-743.

Grummer, R. R. 1991. Effect of feed on the composition of milk fat. J. Dairy Sci. 74:3244-3257.

Grundy, S. M., and M. A. Denke. 1990. Dietary influences on serum lipids and lipoproteins. J. Lipid Res. 31:1149-1172.

International Dairy Federation. 1987. Milk: Determination of fat content - Röse Gottlieb gravimetric method (reference method). In International Dairy Federation Standard FIL-IDF. Int. Dairy Fed., Brussels, Belgium.

Ip, C., S. Banni, E. Angioni, G. Carta, J. McGinley, H. J. Thompson, D. Barbano, and D. Bauman. 1999. Conjugated linoleic acidenriched butter fat alters mammary gland morphogenesis and reduces cancer risk in rats. J. Nutr. 129:2135-2142.

Kay, J. K., T. R. Mackle, M. J. Auldist, N. A. Thomson, and D. E. Bauman. 2004. Endogenous synthesis of cis-9, trans-11 conjugated linoleic acid in dairy cows fed fresh pasture. J. Dairy Sci. 87:369378.

Kay, J. K., J. R. Roche, E. S. Kolver, N. A. Thomson, and L. H. Baumgard. 2005. A comparison between feeding systems (pasture and TMR) and the effect of vitamin E supplementation on plasma and milk fatty acid profiles in dairy cows. J. Dairy Res. 72:322332.

Kennedy, J., P. Dillon, L. Delaby, P. Faverdin, G. Stakelum, and M. Rath. 2003. Effect of genetic merit and concentrate supplementation on grass intake and milk production with Holstein-Friesian dairy cows. J. Dairy Sci. 86:610-621.

Kolver, E. S., and M. J. de Veth. 2002. Prediction of ruminal pH from pasture-based diets. J. Dairy Sci. 85:1255-1266.

Kolver, E. S., J. R. Roche, M. J. de Veth, P. L. Thorne, and A. R. Napper. 2002. Total mixed rations versus pasture diets: Evidence for a genotype $\times$ diet interaction in dairy cow performance. Proc. N.Z. Soc. Anim. Prod. 62:246-251.

Lawless, F., C. Stanton, P. L'Escop, R. Devery, P. Dillon, and J. J. Murphy. 1999. Influence of breed on bovine cis-9, trans-11conjugated linoleic acid content. Livest. Prod. Sci. 62:43-49.

Lock, A. L., and P. C. Garnsworthy. 2003. Seasonal variation in milk conjugated linoleic acid and $\Delta^{9}$-desaturase activity in dairy cows. Livest. Prod. Sci. 79:47-59.

Moate, P. J., W. Chalupa, T. C. Jenkins, and R. C. Boston. 2004. A model to describe ruminal metabolism and intestinal absorption of long chain fatty acids. Anim. Feed Sci. Technol. 112:79-105.

Murphy, J. J. 2000. Synthesis of milk fat and opportunities for nutritional manipulation. Pages 201-222 in Milk Composition. R. E. Agnew, K. W. Agnew, and A. M. Fearon, ed. Br. Soc. Anim. Sci., Edinburgh, UK.

National Research Council. 2001. Nutrient Requirements of Dairy Cattle. 7th rev. ed. Natl. Acad. Sci., Washington, DC.

Palmquist, D. L., A. D. Beaulieu, and D. M. Barbano. 1993. Feed and animal factors influencing milk fat composition. J. Dairy Sci. $76: 1753-1771$ 
Palmquist, D. L., C. L. Davis, R. E. Brown, and D. S. Sachan. 1969. Availability and metabolism of various substances in ruminants. V. Entry rate into the body and incorporation into milk fat of $\mathrm{D}(-)$ 3-hydroxybutyrate. J. Dairy Sci. 52:633-638.

Parodi, P. W. 2003. Conjugated Linoleic Acid in Food. Pages 101122 in Advances in Conjugated Linoleic Acid Research, Vol. 2. J.-L. Sebedio, W. W. Christie, and R. O. Adlof, ed. AOCS Press, Champaign, IL.

Perfield, J. W., P. Delmonte, A. L. Lock, M. P. Yurawecz, and D. E. Bauman. 2006. Trans-10, trans-12 conjugated linoleic acid does not affect milk fat yield but reduces $\Delta^{9}$-desaturase index in dairy cows. J. Dairy Sci. 89:2559-2566.

Roche, J. R., D. P. Berry, and E. S. Kolver. 2006. Holstein-Friesian strain and feed effects on milk production, body weight, and body condition score profiles in grazing dairy cows. J. Dairy Sci. 89:3532-3543.

Roche, J. R., P. G. Dillon, C. R. Stockdale, L. H. Baumgard, and M. J. VanBaale. 2004. Relationships among international body condition scoring systems. J. Dairy Sci. 87:3076-3079.

Slover, H. T., and E. Lanza. 1979. Quantitative analysis of food fatty acids by capillary gas chromatography. J. Am. Oil Chem. Soc. 56:933-943.
Standing Committee on Agriculture. 1990. Feeding Standards for Australian Livestock. Ruminants. CSIRO Publ., Melbourne, Australia.

Stockdale, C. R., G. P. Walker, W. J. Wales, D. E. Dalley, A. Birkett, Z. Shen, and P. T. Doyle. 2003. Influence of pasture and concentrates in the diet of grazing dairy cows on the fatty acid composition of milk. J. Dairy Res. 70:267-276.

Ulyatt, M. J., J. Lee, and D. Corson. 1995. Assessing feed quality. Pages 59-62 in Proc. Ruakura Farmers Conf., Hamilton, New Zealand.

Van Soest, P. J., J. B. Robertson, and B. A. Lewis. 1991. Methods for dietary fiber, neutral detergent fiber, and nonstarch polysaccharides in relation to animal nutrition. J. Dairy Sci. 74:3583-3597.

White, S. L., J. A. Bertrand, M. R. Wade, S. P. Washburn, J. T. Green Jr., and T. C. Jenkins. 2001. Comparison of fatty acid content of milk from Jersey and Holstein cows consuming pasture or a total mixed ration. J. Dairy Sci. 84:2295-2301.

Wijesundera, C., Z. Shen, W. J. Wales, and D. E. Dalley. 2003. Effect of cereal grain and fibre supplements on the fatty acid composition of milk fat of grazing dairy cows in early lactation. J. Dairy Res. $70: 257-265$. 